\title{
Community Policing Law Enforcement in Handling Narcotics Crimes by Children
}

\author{
Zulkarnain \\ Student of Doctoral Study Program \\ Lampung University \\ Lampung, Indonesia \\ zulkarnain.policia@gmail.com
}

\begin{abstract}
This study aims to examine law enforcement carried out by community policing in tackling narcotics crimes by children. As the era progressed, more and more crimes occurred, starting from minor crimes to serious crimes. One form of crime or crime is the abuse of narcotics by children. Narcotics crimes by children can be seen from the point of view of children as perpetrators and victims. Basically, against narcotics crimes, children tend to be victims, because children cannot be punished before reaching a predetermined age, so children tend to be processed in the form of diversion. Diversion is carried out because children are the responsibility of parents, so that against criminal acts of children, law enforcement is to seek the best interests of children. In responding to this, community policing or Community Policing (Polmas) is at the forefront in tackling drug abuse. One of the patterns that can be done by the State security is to build partnerships between the Police (Bhabinkamtabmas) with the community and village government. In conducting a partnership pattern, a Bhabinkamtibmas is required to have good communication skills and also the ability to be able to embrace all elements in the community so that the partnership pattern can run well. Bhabinkamtibmas plays a very important role in the implementation and success of the crime prevention system in the field of narcotics carried out by children. The strategy in implementing community policing from a Police and Community Communication Forum (FKPM) aims to create security and order in the community that is run by the community together with members of the police. At the kelurahan level, FKPM has the task of creating security and order in the local kelurahan or village environment.
\end{abstract}

Keywords-Law Enforcement, Narcotics, Children, Community Policing

\section{INTRODUCTION}

Circulation of narcotics in Indonesia, seen from the juridical aspect, is legal. This regulation only prohibits the use of narcotics without permission by law. This situation is often misused and not for the benefit of health but more than that, which is used as a business object (economy) [1]. Law enforcement against narcotics abuse has been widely carried out by law enforcement officers and has received many decisions in court. This law enforcement is expected to be able to act as an antidote to the spread of narcotics trafficking. With the spread of narcotics dealers which have a negative impact on people's lives. So, to control and restore the ideal conditions of community life (orderly, safe, and peaceful) the role of the police is needed [2].

The Indonesian National Police (Polri) is a state instrument that has the main task of maintaining public security and order, enforcing the law and providing protection, protection, and services to the community, as stipulated in Law Number 2 of 2002 concerning the Indonesian National Police. The National Police is responsible for seeking, preventing, and eliminating any symptoms that may appear and may disrupt security and order in the community. Community security and order is a situation that is needed to support the implementation of development and all community activities [3].

The situation of Community Security and Order (Kamtibmas) is highly expected by the whole community to be realized, thereby creating a feeling of peace and peace for every community and can increase motivation and enthusiasm at work, because there is no fear due to possible disturbances that will befall. The Police have a tough task in preventing violations and crimes, serving the community and protecting and bringing order to the community.

In this case, the Police themselves have prepared personnel who represent the field of community development. The point is to build a partnership between the Police and the community so that mutual trust, mutual respect and respect between the Police and the community are realized. The police can be accepted and supported by the community [4]. Police activities to encourage, direct, and mobilize the community to play a role in Binkamtibmas (Guidance for Community Security and Order) through the form of Pamswakarsa and the application of the community policing model (Community Policing) among others through the 
assignment of members of the Police to become Bhayangkara Pembina Kamtibmas (Bhabinkamtibmas) which refers to Letter of the Head of the State Police of the Republic of Indonesia Number: B/3377/IX/2011/Baharkam dated September 29, 2011 concerning the Deployment of Bhabinkamtibmas in Villages/Kelurahan.

The Bhayangkara for the Development of Community Security and Order (Bhabinkamtibmas) is a member of the National Police who is tasked with fostering public security and order (kamtibmas). The goal to be achieved in the Bhabinkamtibmas activity is the realization of a stable and dynamic security and security situation in order to secure and succeed in national development [5]. Whereas what is meant by kamtibmas is a dynamic condition of society which is characterized by ensuring order and law enforcement and the establishment of peace which contains the ability to foster and develop the potential and strength of the community in preventing, preventing and overcoming all forms of law violations and other forms of disturbance that can be troubling. community, which is one of the prerequisites for the implementation of the national development process.

The main guideline for the implementation of Bhabinkamtibmas duties is the Field Manual on Bhabinkamtibmas in Villages/Kelurahan No.Pol.: Bujuklap/17/VII/1997 which has been amended by Decree of the Chief of Police No.Pol.: Kep/8/XI/2009 dated 24 November 2009 concerning Amendment to the National Police Chief Field Manual No.Pol.: Bujuklap/17/VII/1997, amended again by Decree of the National Police Chief No.Pol.: Kep/618/VII/2014 which became the Bhabinkamtibmas Smart Book 2014, Law No. 2 of 2002 concerning the National Police of the Republic of Indonesia, and Policies and Strategies of the Police.

Bhabinkamtibmas is a program of the National Police Headquarters to bring the police closer and build partnerships with the community. Bhabinkamtibmas realizes the mission of serving the community in a tangible form so that the role of the police can be felt directly by the village community in the form of a service approach. Gaining the trust of the public is difficult to obtain, because it requires a process, especially communication and social contact, the time and willingness of each member of the police [6]. The community still expects an increase in the role and duties of the police as protectors, protectors, and community services as well as clean law enforcers.

Since the separation of POLRI from the Armed Forces of the Republic of Indonesia (ABRI) on April 1, 1999, POLRI has also become a part of a civilian government agency whose main objective is to protect, protect, and serve the community. From these reform efforts, the development of the community policing (POLMAS) system was carried out. The essence of this effort is to emphasize the cooperation between the
Police and the community in solving problems, preventing threats to security and order in society. The basic thing at this time is why the National Police creates a policy on Polmas [7].

Has this Polmas been introduced, realized to the community by members of the Police. Then what are the obstacles that arise in implementing a system that is the mainstay of the Police. And how is the community in implementing the efforts of the Police in building cooperation with the community, in facing a problem in the form of threats to security and order in people's lives What things must be done by the community to community organizations in the context of implementing the Polmas, so as not to change the system into an effort to "mobilize" the Police against community groups.

The rise of illicit drug trafficking which has spread to all levels of society, including among the younger generation as the successor of the Indonesian nation will greatly affect the life of the Indonesian nation and state in the future [8]. Narcotics are very influential on the physical and mental of everyone who uses them. Narcotics abuse not only endangers the addicts themselves but can have further consequences, namely changing the order of people's lives which can have an impact on the collapse of a country. Narcotics can be a ticking time bomb for the country if prevention is not done as soon as possible. The police as law enforcement officers play an important role in eradicating all crimes.

Handling in tackling the abuse of drug trafficking which is increasingly widespread is considered very important in protecting the community, considering that the health of people's lives is the main which is judged to be a good country from the level of welfare of its people. The number of levels of drug users in Indonesia makes this country a target for drug trafficking.

Law Number 23 of 2002 concerning Child Protection states that in order for every child to be able to assume this responsibility later, he needs to get the widest opportunity to grow and develop optimally, both physically, mentally and socially, and with noble character. For this reason, it is necessary to protect children's welfare by providing guarantees for the fulfillment of children's rights and treatment without discrimination.

Prior to Law Number 11 of 2012, the juvenile court process was regulated by Law Number 3 of 1997 concerning the Juvenile Court System as an effort to foster and protect in order to ensure the physical, mental, and social growth and development of children as a whole, harmonious and harmonious. and Therefore, the provisions regarding the administration of courts for children are carried out specifically. However, the applicable procedural law (KUHAP) is also applied in juvenile court proceedings, unless otherwise stipulated in Law Number 3 of 1997. In 
principle, the duties and authorities of juvenile courts are the same as those of other criminal courts.

A total of 87 million children with a maximum age of 18 years recorded 5.9 million who were exposed as drug addicts, 27 percent of whom were children, namely 1.6 million children as dealers. The data is considered by KPAI to be quite worrying. Moreover, there is a tendency for bookies to continue targeting children as users or couriers. "There are 2,218 cases of children involved in this drug issue. Among them 15.69 percent of cases are users and 8.1 percent of cases are dealers.

Based on Law Number 11 of 2012, the settlement of children's cases prioritizes the process outside the judiciary by involving the perpetrators, victims, families of perpetrators/victims, and other related parties to jointly seek a fair solution by emphasizing the restoration to its original state, and not retaliation to seek restorative justice as regulated in Article 1 paragraph (6) of Law Number 11 of 2012.

Drug trafficking and abuse in society must be prevented and tackled. This prevention effort must really be carried out in accordance with the issuance of the Narcotics Law so that the drug problem does not continue to grow in society as an epidemic that is bad for the development of the country. This legal issue concerns the role of law enforcement officers, especially the police, whose existence is very important in the midst of society as a balancing servant of the state and protector of life in society. Lawrence $M$. Friedman's opinion states that all legal products, both in the form of laws and regulations, will definitely have an impact on the performance of law enforcement officers.

Prevention and control efforts carried out by the Police in this case require further steps in the law enforcement process against perpetrators of drug trafficking. The realization of overcoming the eradication of drug trafficking cannot be separated from the role of law enforcement officers, it requires cooperation from various parties, including community participation.

\section{LITERATURE REVIEW}

\section{A. Bhabinkamtibmas. Concept}

Bhabinkamtibmas is the spearhead of the implementation of the Community Policing (Community Policing) program or what is known by the abbreviation Polmas which means an activity to invite the community through partnerships between Polri members and the community, so that they are able to detect and identify problems of security and public order (Kamtibmas) in the environment and find solutions. the problem [9]. (Perkap No. 3 of 2015 concerning Community Policing, 2015:4) Bhabinkamtibmas who is a community officer (police officer) is a member of the National Police who is tasked with fostering Kamtibmas and is also a Polmas officer in villages/kelurahan.

Polmas as a new strategy set by the National Police is an effective way to build cooperation/partnership between the police and the community and at the same time guarantee the protection of human rights. This partnership will enable the community to understand the main duties and roles of the police [10]. In this way, the community will be able to identify various social problems, especially with regard to security and safety and ultimately be willing and able to work together with the police to prevent and at the same time eradicate crime.

Traditionally, the communication carried out by the Police is by developing Community Development programs (Binmas) and programs related to the selfhelp security system (Siskamswakarsa). The siskamswakarsa program is carried out through an environmental security system (Siskamling) which includes a residential environment, an educational environment and a work environment as forms of independent security as stipulated in the Law on the Indonesian National Police. In this case Bhabinkamtibmas acts as the spearhead of the implementation of siskamling/siskamswakarsa [11].

In line with the reform process that has been and is ongoing towards a democratic civil society bringing changes in the joints of social life, the National Police, which is currently carrying out the reform process to become a civilian police force, must be able to adapt to the development of people's lives by changing patterns of behavior. communication that focuses on a reactive and conventional approach (power) towards a proactive approach and gains public support by prioritizing partnerships in the context of solving social problems [12]. Communication as a component of Community Policing (Polmas) is the main ability that needs to be possessed.

\section{B. Police Relations with the Community}

As a system, there are a number of elements in Polmas. However, in practice what absolutely must be sought are 2 (two) core components of Polmas, namely partnership and problem solving. An absolute component that must be realized by officers in the implementation of Polmas is the existence of an equal partnership between the police and the community. The second component that must also be realized by officers in the implementation of Polmas is problem solving [13]. This means that Polmas activities are focused as much as possible on solving problems. Partnerships are built between the police and the community. intended as a vehicle for solving various problems both within the scope of settlements, education or communities in anticipating the occurrence of various problems.

The ideal police figure around the world is a policeman who fits into society [14]. With this principle, the community expects a police who is 
compatible with the community, which changes from an antagonistic police (a policeman who is insensitive and runs a policing style that is contrary to the community) to a protagonist police (open to the dynamics of changing society and willing to accommodate him in his duties).

With the rapid socio-cultural development and society demands a democratic civilian police in the form of a modern and democratic police [15]. With the main foundation is a sincere relationship between the police and the community which is followed up by implementing strategies or policies to get more effective and efficient results in controlling crime. Where the police are aware of their abilities that do not know when and where crimes occur and who the perpetrators are.

\section{Drugs}

Drugs are drugs to calm nerves, relieve pain, and sleep (can be intoxicating, so they are prohibited from being sold to the public). Drugs have many kinds, shapes, colors, and effects on the body. However, of the many kinds and forms, drugs have many similarities, including the nature of addiction (addiction), tolerance (adjustment) and very high habitual power [16]. These three characteristics cause drug users to be unable to escape from their "grip".

Drugs consist of two substances, namely narcotics and psychotropic substances. And specifically, these two substances have different meanings, types (classes), and are regulated by different laws. Narcotics are regulated by Law No. 35 of 2009, while psychotropics are regulated by Law No. 5 of 1997. These two laws are steps by the Indonesian government to ratify the 1988 United Nations Conference on Illegal Psychotropic Narcotics. Narcotics, as stated in article 1 Law No. 22 of 1997 is defined as a substance or drug derived from plants or non-plants, either artificial or semi-artificial which can cause a decrease or change in consciousness, reduce to cause pain and can cause dependence.

Hari Sasangka also explained that other definitions of narcotics are opium, marijuana, cocaine, substances whose raw materials are taken from these objects, namely morphine, heroin, codeine, hashish, cocaine. And also includes synthetic narcotics that produce substances, drugs belonging to the Hallucinogens, Depressants, and Stimulants.

\section{RESEARCH METHODS}

Research has another term or known as research. Research comes from English, namely research which comes from the word re (re) search (search) thus research which has the term research can be interpreted as searching again. This research activity is based on the curiosity of someone who is then referred to as a researcher in carrying out research activities. Research is a form of expression of curiosity carried out in the form of scientific research activities. This research is carried out with a sense of trust in the object being researched by finding out the causes and effects that arise or occur in the object of research.

This study uses a normative research method. Normative legal research is a process to find a rule of law, legal principles, and legal doctrines in order to answer the legal issues faced. In this type of legal research, law is often conceptualized as what is written in legislation or the law is conceptualized as a rule or norm which is a benchmark for human behavior that is considered appropriate.

Based on the problem approach and the required data sources, the data collection in this study was carried out by means of a literature study by reading, quoting, taking notes, and identifying data that was in accordance with the problem and collaborating with the data of applicable laws and regulations. After collecting data, then processing the data obtained is used to analyze the problems studied. Data processing in this study was carried out by: Data examination, classification and data compilation.

\section{RESULTS}

Law enforcement is defined as a process to realize the wishes of the law, namely the thoughts of the legislatures that are formulated and stipulated in legal regulations which later become reality [17]. Furthermore, law enforcement can be defined as an activity to harmonize the relationship of values that are spelled out in solid methods and manifest in attitudes and actions as a series of elaboration of values at the final stage, to create and maintain, and maintain peace and association. Conceptually, the essence and meaning of law enforcement lies in social life.

The elements of law enforcement can be divided into 3 (three) parts, namely the first legislation, namely a collection of regulations that apply binding and coercive and accompanied by sanctions for violators, secondly law enforcers in this case the police, prosecutors, judges and advocates, determine whether or not the law is implemented properly [18]. The three communities themselves where the level of awareness and/or knowledge of the law will determine the achievement of law enforcement.

In general, law enforcement in Indonesia is carried out in 2 (two) ways, namely [19]:

1) Preventive is an effort made to prevent the occurrence of an act that violates the law. Muladi's opinion as quoted by Rusli Muhammad, when viewed from a policy process, then law enforcement is essentially a policy enforcement through several stages, namely: 
a) The formulation stage, namely the law enforcement stage in abstract by the legislature, at this stage is called the legislative policy stage.

b) The application stage, namely the enforcement of criminal law by law enforcement officers starting from the police, courts, this stage is called the judicial policy stage.

c) The execution stage, namely the stage of concrete implementation of criminal law by criminal implementing officers, this stage is called the executive or administrative policy stage.

2) Repressive Law Enforcement Efforts This form of law enforcement is taking action when or when a crime has been committed. The prosecution has several stages from the beginning of the investigation to the court, including:

a) Investigation, which is a series of investigators' actions to seek and find an event that is suspected of being a criminal act in order to determine whether or not an investigation can be carried out. (Article 1 paragraph 5 KUHAP)

b) Investigation, namely a series of actions by investigators to seek and collect evidence that occurred and to find the suspect. (Article 1 paragraph 2 of the Criminal Procedure Code)

c) Arrest, which is an action by an investigator in the form of a temporary restraint on the freedom of a suspect or defendant if there is sufficient evidence for the purposes of investigation or prosecution and/or trial.

d) Detention, namely the placement of a suspect or defendant in a certain place by an investigator, or a public prosecutor or judge with his determination. (Article 1 paragraph 21 KUHAP)

e) Prosecution, namely the action of the public prosecutor to delegate a criminal case to an authorized district court with a request that it be examined and decided by a judge in court. (Article 1 paragraph 7 of the Criminal Procedure Code)

f) To adjudicate, namely the act of judges to accept, examine and decide criminal cases based on the principles of being free, honest and impartial in court. (Article 1 paragraph 9 of the Criminal Procedure Code)

g) Court decision, namely a judge's statement pronounced in an open court session, which can be in the form of punishment or acquittal or free from all lawsuits. (Article 1 paragraph 11 of the Criminal Procedure Code)

When talking about law enforcement, it is certain that it can have a way of referring to the provisions of the laws and regulations that have passed. One instrument of criminal law enforcement is community policing (Polmas). Community policing has been adopted by many European and American countries for the past few years. In practice, there are indeed many variations developed by each country, according to the character and culture of the existing society. However, in principle, the implementation of the community policing system is always based on the principle that law and public order (law and order) cannot be handled only by law enforcement officers themselves. Rather, it is through close cooperation between the police and the community [20].

Fighting crime requires good cooperation with society. The form of cooperation between the police and the community in fighting crime is partnership. Cooperation with the community means adopting a policing perspective that goes beyond the standard which only emphasizes law enforcement. Such a broad view recognizes that activities that contribute to the order and well-being of a particular environment have a high value [21]. The relationship between the police and the community is mutually influencing, in the sense of the word that the resolution of problems in the community can be resolved properly when there is a good bond/cooperation between the community and the Police.

The purpose of community policing is to deal with or prevent criminal acts by understanding the characteristics of a dispute that is currently occurring in a particular environment. The results obtained will be analyzed and negotiated together, through the cooperation that has been built by the police and the community. Building and fostering mutual trust is the goal in building a partnership with the community. It is the initial stage that both parties must have a desire to establish a cooperation [22]. The police must recognize the importance of cooperation with the community and the benefits that can be obtained from such cooperation. Meanwhile, the community must also realize the need to create strong cooperation with the police in order to create a safe, orderly, and peaceful area. and free from fear. There are so many factors that hinder the creation of mutual trust in one another, especially in Indonesia. For decades, people have experienced a policing system that tends to be militaristic. This is the cause of the emergence of distrust of the police.

Some of the classifications of criminal cases that can be resolved by Polmas officers based on the rules in the elaboration or derivatives of Jakstra Polmas are Violations in Article 489-569 of the Criminal Code, with a maximum imprisonment of 3 months and a maximum fine of IDR 7,500. The Criminal Code is described in Article 302, which is about light abuse of animals, 352 mistreatment of humans, 364 light theft, 373 light embezzlement, 379 light fraud, 482 light arrests, 315 light insults. In 2008 Jakstra Polmas was 
strengthened through the National Police Chief Regulation No. 7/2008. However, there is a lack of satisfaction, the Police continue to try to perfect the concept in terms of "Penal Mediation" through the National Police Chief's Letter No. Pol.: B/3022/XII/2009/Sdeops issued on Date.

The strategy in forming members of the Kamtibmas awareness group is that individuals serve voluntarily because they are driven by a sense of responsibility as citizens because they love Kamtibmas and do not expect material rewards and have a high sense of social responsibility [23]. The selection of members of the Kamtibmas awareness group is carried out entirely by Babinkamtibmas by first approaching the Village Head, Head of LKMD and community leaders, so that before being recruited into FKPM, Babinkamtibmas first gets to know each prospective FKPM personnel personally. After selecting the candidates for FKPM members, then the results of the selection are submitted to the Head of the Village/Lurah and the Head of LKMD either orally or in writing. Furthermore, through the Chief of Police,

The guidance on FKPM mandated to Babinkamtibmas includes the following [24]:

- Babinkamtibmas is responsible for the direct guidance of FKPM,

- Babinkamtibmas is obliged to visit FKPM in every village/kelurahan that is under its guidance,

- In every meeting, Babinkamtibmas provides directions that need to be conveyed regarding binkamtibmas, and vice versa Babinkamtibmas receives input or information from FKPM members in the context of binkamtibmas, so as to create two-way communication,

- FKPM activity plans are recorded in a special book known to Babinkamtibmas.

- The meeting between Babinkamtibmas and FKPM is held at least once a week,

- The police chief comes face to face with each FKPM at least once every three months, taking turns as well as incidentally as needed.

- The Chief of Police meets face-to-face with all FKPM members in his area at least once every six months,

- Sanctions that must be imposed on FKPM members who commit disgraceful acts are as follows:

1) The police chief must give warnings and warnings.

2) If the act is a crime, the Police Chief is obliged to terminate his membership status.
The process of implementing Polmas needs to be structured as a "community profile." This will assist officers in carrying out their roles. With the availability of community profiles, police officers from Polmas will be assisted in organizing information about the community in question, which will later be useful in planning various security strategies [25]. This profile includes identification of crime problems and public security issues given or submitted by local residents and businessmen. Community profiling is also the first step in developing services that are responsive to the needs and thoughts of the community. Furthermore, the results will be very helpful in identifying key stakeholders and potential participants in community and police relations.

Efforts to overcome drug abuse (narcotics, psychotropics and illegal addictive drugs) can be carried out through four different stages, including [26]:

- Pre-emptive efforts are efforts to eliminate an action involving the interests of many people before the action occurs. This effort is done by eliminating the underlying factor (correlative chrominogen), in other words eliminating the underlying factor causing the abuse, among others through increasing public awarenessbuilding campaigns.

- Preventive efforts are actions to prevent drug crimes not only carrying out guard and patrolling, but also taking other preventive measures in the form of improving the surveillance system for drugs from abroad and conducting surveillance of drug use for drugs in a reasonable manner.

- Repressive measures are efforts to take action against perpetrators who commit criminal acts of procurement and use of drugs to be processed in accordance with applicable law.

- Rehabilitation efforts are efforts to help, care for and rehabilitate victims of drug abuse in certain institutions, so that it is hoped that the victims can return to the community.

The model of community policing in carrying out the duties of the National Police which underwent the latest changes to the Regulation of the Chief of Police of the Republic of Indonesia Number 3 of 2015 (Perkap Kapolri No. 3 of 2015). The core of this program's objective is the establishment of synergy and cooperation between the National Police and all elements of society for early detection of potential crimes that may occur in the community.

Members of Bhabinkamtibmas are messengers from the Police to be then conveyed to the public to be obeyed, both in the form of rules and other important information. In terms of the early detection process by Bhabinkamtibmas in narcotics crimes, members need to work together with the community to be able to 
convince the community to cooperate in helping reduce crime rates, especially the circulation and use of narcotics by children. Partnerships with the community are very important to get solutions to problems in the field, detect social problems and disturbances and maintain environmental security [27].

In this effort, the principles that must be owned and carried out by officers in carrying out their duties consist of 6 principles of community policing and are also listed in the National Police Chief's Regulation No. 7 of 2008 concerning Basic Guidelines for Strategy and Implementation of Community Policing in Carrying Out Police Tasks. Below the author explains as follows [28]:

a) Intensive communication: The community and members of the police must have one goal and agreement, so to achieve this, members of the bhabinkamtibmas need to take persuasive actions to convince the community and be close to the community. Officers establish intensive communication through various ways that are carried out.

b) Equality: The existence of media that covers several police officers who are involved in criminal acts or acts arbitrarily against the community often creates estrangement in the relationship between the police and the community. People feel distrustful of the police or fear of members of the police which makes the relationship between the police and the community not harmonious. Bhabinkamtibmas members have an important role in building equality of position with the surrounding community so that people are free to express opinions, and obtain the same rights and obligations.

This equality will reduce the distance between the police and the community, as well as to allow for equality in discussions to formulate solutions to problems faced. The principle of equality then becomes important because community policing will not be realized if in its implementation it does not emphasize the relationship that upholds the values of equality and displays a polite attitude, mutual respect between the police and the community.

c) Partnership: The process of establishing a partnership between members of Bhabinkamtibmas and the community is to establish a FKPM forum. As an organizational philosophy and strategy, community policing encourages the creation of a new partnership between the police and the community. By implementing community policing, the partnership between the police and the community will improve. The consequence of the closeness between the police and the community is the increasing activity of associations to prevent acts of brawl by the community. The partnership between the police and the citizens can be seen from the establishment of brawl prevention associations managed by residents and the existence of an institution or forum that accommodates the relationship between the police and the community.

d) Transparency: Transparency is an open attitude that needs to be carried out by both parties, both the police and the community, as well as other parties related to efforts to create a sense of security and prevent narcotics cases. The principle of transparency carried out by members of Bhabinkamtibmas that researchers see is only as far as the description of the security situation, problem occurrences and solutions are to the community. However, this principle has not been fully implemented because when it comes to the task accountability report, there is still no openness between the officers and the citizens.

e) Participation:The participation process requires police and community awareness to actively participate in various community/community activities to encourage citizen involvement in an effort to maintain a sense of security and order, provide information, suggestions and input, and be active in the decision-making process to solve security and security issues, Bhabinkamtibmas members of course, involving the community to play a role in preventing crime, especially narcotics crimes and keeping the community environment safe and conducive.

Protection of children in conflict with the law is an effort to protect children and their rights so that they can grow and develop optimally without violence and discrimination. increasing, of course, very concerning where the perpetrators are not only adults but are also carried out by children, basically criminal acts committed by children and adults are no different, it's just that the difference can be seen from the perpetrators who are underage and adults. 29].

Against children who become intermediaries for buying and selling narcotics, Law No. 35 of 2009 concerning Narcotics does not specifically regulate the provisions of criminal sanctions for children, but basically if a child commits a criminal act of Narcotics where a child who is an intermediary for buying and selling to carry out a process of illicit narcotics trafficking remains entangled with the articles as stated determined in the criminal provisions regulated in the Narcotics Law, but does not override the special provisions regulated in Law No. 11 of 2012 concerning the Juvenile Criminal Justice System.

The police must put pressure on the prison authorities, especially on prisons, to look for the relevant officers who are suspected of facilitating access to the entry of communication media in the form of cellphones into the prison area. HP as a means to control drug trafficking is evidence of the failure of the prison in its participation in monitoring and preventing drug trafficking from within the prison. This failure can 
be said to be evidence of a flawed institutional system in Indonesia [30].

If we further emphasize the use and distribution of drugs by children, then one of the factors that can be improved is the culture in law enforcement. Children as perpetrators of narcotics crimes cannot be treated like adults. Although this is because children are still included in the guidance and supervision of parents.

In giving sanctions to children who are perpetrators of narcotics crimes, law enforcement officers, especially the police, can do several things that can be used as sanctions. These sanctions not only provide a deterrent effect to perpetrators of narcotics crimes committed by children. The transaction can be carried out as follows [31]:

- The punishment given can be in the form of social sanctions that can provide moral lessons for children;

- Children as perpetrators of narcotics crimes can be given a punishment that is economically beneficial, namely by opening a business field.

- Sanctions for children who do narcotics crimes can be in the form of light punishment from parents, by doing rehabilitation independently at home and being given religious education and Pancasila values.

In protecting children who are victims of narcotics addicts, parents or guardians of children who become victims of narcotics addicts are obliged to report to officials appointed by the government for treatment and care. These provisions are contained in Article 55 of Law no. 35 of 2009 concerning Narcotics, which reads as follows:

- Parents or guardians of Narcotics Addicts who are not old enough are required to report to public health centers, hospitals, and/or medical rehabilitation and social rehabilitation institutions appointed by the Government to receive treatment and/or treatment through medical rehabilitation and social rehabilitation.

- Narcotics addicts who are old enough are required to report themselves or be reported by their families to public health centers, hospitals, and/or medical rehabilitation and social rehabilitation institutions appointed by the Government to receive treatment and/or treatment through medical rehabilitation and social rehabilitation.

Community participation in the context of state administration contains the following rights and obligations [32]:

- The right to seek, obtain and provide information regarding state administration.
- The right to obtain equal and fair services from state administrators.

- The right to convey advice and income in a responsible manner towards state administration policies.

- The right to obtain legal protection in this case exercises his rights and if he is present in the process of investigation, investigation, and in court as a reporting witness, witness or expert witness in accordance with the provisions of applicable laws and regulations by complying with religious norms and other social norms.

- Legal awareness of the community and law enforcers in an interactive spirit between legal awareness, perception of justice.

Muladi in his view of guaranteeing certainty, order, law enforcement and legal protection in the era of globalization identified that in the past, rapid social change due to the modernization process was felt as something that could potentially cause social unrest and tension. tensions [33]).

Actual law enforcement will be far from ideal law enforcement (total enforcement and full enforcement) the law will only protect the powerful, and human rights violations occur, and so on. This is where the problem of legal certainty, legal order and legal protection will be felt as a need that basically contains two things, namely safe (physical) and peaceful (inner) all of which can be included in the purpose of law, namely peace (the function of law is to maintain peace) [34].

- Law enforcement itself must be interpreted in three conceptual frameworks, namely: the total enforcement concept which demands that all values behind the legal norms be enforced without exception;

- A full enforcement concept that realizes that the total concept needs to be limited by procedural law and so on for the protection of individual interests;

- The concept of actual law enforcement that emerged after it was believed that there was discretion in law enforcement due to limitations, both related to infrastructure, quality of human resources, quality of legislation, and lack of community participation.

The community is made like an investigator by seeking, obtaining, and providing information and getting services in these matters [35]. In this law, the public is not given the right to provide counseling, assistance and strengthening of narcotics addicts. Law Number 35 of 2009 concerning Narcotics Article 104 and Article 54 of Law Number 5 of 1997 concerning Psychotropics emphasizes that the community has the widest opportunity to participate in assisting the 
prevention, eradication of abuse and illicit trafficking of narcotics and Narcotics precursors.

The police as law enforcers have a very important role in combating the abuse and illicit trafficking of narcotics and psychotropic substances. The role of the Police in overcoming narcotics and psychotropic crimes. In this case, the role of the Police is not as an investigator, but as a police officer who provides protection and guidance as well as law enforcement against the dangers of narcotics and psychotropic abuse in people's lives [36].

General preventive strategy, or it can be said as the role of the non-penal police, because in carrying out the strategy it is not at all related to the judicial process. This strategy is carried out outside the judicial process. This strategy in the field of prevention is carried out by the Police in collaboration with BNN, which in this strategy is carried out in several stages in society starting from the lowest level, namely the family, to the highest level, namely the community.

The forms of strategy in the field of prevention can be in the form of appeals, seminars and anti-narcotics movements, distributing posters and appeal boards with the theme of anti-narcotics, and also printing special anti-narcotics magazines to make the strategy in the field of narcotics a success. prevention of drug abuse.

National Strategy for Communication, Information, and Prevention Education In this strategy, as revealed by Wiryono in his theory, he said that prevention is carried out by normalizing, namely by providing education, announcements, and clear knowledge to the public of a crime [37]. It means that the public must be notified in advance that the act is wrong if it is done, namely by conducting seminars and appeals.

Similarly, in the prevention of drug abuse, it is mainly directed to the younger generation such as children, youth, students, youth and university students. Drug abuse is the result of complex individual interactions by sharing elements of the environment, especially with parents, schools, communities, and other youth or youth. Therefore, information communication strategies and prevention education are implemented through approaches with family, education, peers and so on.

The Pre Emtip strategy against narcotics crimes committed by the police by children, namely [38]:

- Actively educative means, that is active in conducting education and providing information about the dangers of drugs to the community. For example: holding anti-drug seminars, drug counseling, and so on;

- Promotive activity: It means being active in carrying out activities that promote the dangers of drug abuse, for example: distributing brochures, warning boards about the dangers of drugs;

- Fostering a healthy lifestyle for the community provides guidance to the community on the importance of living a healthy life without drug addiction, for example: conducting drug counseling in remote places.

Basically, community policing law enforcement is an effort made by the police in an effort to prevent the occurrence of a narcotics crime by children. The most basic thing in law enforcement against children is "the best interests of the child". Children in a narcotics crime are not punished as perpetrators, but punishments as victims of crime [39].

Children as victims of crime must be protected even though the child's actions have met the requirements of a crime. Basically, crime prevention efforts with criminal law are essentially part of the effort to enforce criminal law itself. However, the enforcement of criminal law must be accompanied by retaliation against child victims in narcotics crimes. Thus, in law enforcement carried out by community policing, it must follow the provisions of the legislation, namely the application of diversion to children as victims of crime.

Law Number 11 of 2012 concerning the Juvenile Criminal Justice System requires every law enforcement officer, be it the Police, Prosecutors and Judges, to diversify cases of crimes committed by children. This is confirmed in Article 7 paragraph (1) of Law Number 11 of 2012 concerning the Juvenile Criminal Justice System which states that at the level of investigation, prosecution and examination of children's cases in district courts, diversion must be sought. The statement of this article shows that as far as possible the criminal acts committed by children are attempted not to proceed to the level of examination in court to sentencing, but strive to restore it to its original condition because it is related to the condition and mental development of the child who is still unstable.

Lack of understanding of the concept of diversion evenly by the police, although there are police who know about the concept of diversion but are not implemented. Children who abuse narcotics are not only as perpetrators of criminal acts, but also as victims, that children who abuse narcotics are also victims, so efforts to provide protection for children who abuse narcotics are also a priority.

The conditions for the implementation of diversion in resolving criminal acts committed by children include the age of the perpetrator who must really be a child according to the law, the existence of a confession or statement of guilt from the perpetrator and his willingness to do diversion, the consent of the victim to carry out a settlement outside the criminal justice system, the existence of community support to carry out settlements outside the juvenile criminal justice system 
and the category of punishment imposed, namely imprisonment for less than 7 years and not a repetition of a crime.

The role of the child's parents is still lacking in understanding about diversion, because of the limited knowledge of the child's diversion process. The role of community representatives, RT, RW, is still lacking due to ignorance of the diversion process. Based on the results of research in the field, the authors see that the duties and authorities stipulated in Article 6 of the Joint Decree with the reality on the ground still cannot be carried out perfectly.

Apart from the role of parents, the community is also very much needed in the prevention and law enforcement of narcotics crimes committed by children. The community and community policing (Community Police) are the people themselves who make themselves as police, which means that they are ready to be ready to prevent various crimes that may occur, especially drug abuse by children. So that in law enforcement carried out by community policing, it can run according to shared expectations.

\section{CONCLUSION}

In narcotics and psychotropic crimes, the police have a very large role because the police are one of the authorized institutions in overcoming the rise of narcotics and psychotropic crimes, where the role of the police itself aims to provide services, protection and protection to the community. Increasing the active role of the community in supporting/assisting the task of the National Police in maintaining security and order in the area/environment so that it is one of the main tasks of community policing activities so that it is hoped that a conducive security and security situation will be created. In carrying out a partnership pattern, a Bhabinkamtibmas is also required to have good communication skills and also the ability to be able to embrace all elements in the community so that the partnership pattern can work well. Bhabinkamtibmas plays a very important role in the implementation and success of the crime prevention system in the field of narcotics carried out by children. The strategy in implementing community policing from a Police and Community Communication Forum (FKPM) aims to create security and order in the community that is run by the community together with members of the police. At the kelurahan level, FKPM has the task of creating security and order in the local kelurahan or village environment. Bhabinkamtibmas plays a very important role in the implementation and success of the crime prevention system in the field of narcotics carried out by children. The strategy in implementing community policing from a Police and Community Communication Forum (FKPM) aims to create security and order in the community that is run by the community together with members of the police. At the kelurahan level, FKPM has the task of creating security and order in the local kelurahan or village environment. Bhabinkamtibmas plays a very important role in the implementation and success of the crime prevention system in the field of narcotics carried out by children. The strategy in implementing community policing from a Police and Community Communication Forum (FKPM) aims to create security and order in the community that is run by the community together with members of the police. At the kelurahan level, FKPM has the task of creating security and order in the local kelurahan or village environment. The strategy in implementing community policing from a Police and Community Communication Forum (FKPM) aims to create security and order in the community that is run by the community together with members of the police. At the kelurahan level, FKPM has the task of creating security and order in the local kelurahan or village environment. The strategy in implementing community policing from a Police and Community Communication Forum (FKPM) aims to create security and order in the community that is run by the community together with members of the police. At the kelurahan level, FKPM has the task of creating security and order in the local kelurahan or village environment.

\section{REFERENCES}

[1] Azhar, M. Ali. (March 2014). Alternative Empowerment Strategies in Overcoming Drug Abuse and Illicit Trafficking. The paper was presented by the Head of Sub-Directorate for Urban Society of the Directorate of Alternative Empowerment at the National Narcotics Agency at the BNNP Coordination Meeting in Jakarta on March 11, 2014.

[2] Mardani, Drug Abuse in the Perspective of Islamic Law and National Criminal Law, Rajagrafindo Persada, Jakarta, 2008, p. 2

[3] Moch Faisal Salam, Criminal Procedure Law in Theory \& Practice, Mandar Maju, Bandung, 2001. p. 80

[4] Julianan Lisa FR, Nengah Sutrisna W, Narcotics, Psychotropics and mental disorders, Nuha Medika, Yoygakarta, 2013, p.2.

[5] Atwari Bajari, Street Children Communication Dynamics and Deviant Child Behavior (Bandung: Humanities, 2012).

[6] Wagiati Soetedjo, Melani, Child Criminal Law (Bandung: Refika Aditama, 2013), p. 49

[7] Nasir Djamil, Children Are Not To Be Punished (Jakarta: Sinar Graphic, 2013), p. 8

[8] Bismar Siregar, Abdul Hakim Garuda Nusantara, Suwanti Sisworahardjo, Arif Gosita, Law and the Rights of the Child (Jakarta: CV Rajawali, 1986), p. 23

[9] Indonesian Central Bureau of Statistics, "Profile of Indonesian Children in 2018", Journal of the Ministry of Women's Empowerment and Child Protection of Indonesia, Vol. No.2089-3523 (2018), p. 14

[10] Arief Gosita, Child Protection Issues (Jakarta: Akademika Pressindo, 1985), p. 12

[11] Nasharina, Legal Protection for Children in Indonesia (Jakarta: Rajawali Pers, 2011), p. 3

[12] Ahmad sofian, Child Protection in Indonesia Dilemmas and Solutions (Jakarta: Sinar Garfika, 2012), p. 2.

[13] Asmarawati, T. (2014). Criminal and sentencing in the Indonesian legal system. Yogyakarta: Depublish, p. 34

[14] Marlina. (2010). Introduction to the concept of diversion and restorative justice in criminal law. Medan: USU Press, p. 21. 
[15] Sutedjo, W., \& Melani. (2013). Revised edition of juvenile criminal law. Fourth printing. Bandung: PT. Refika Aditama, p. 12.

[16] Sanjaya, AW (2015). The authority to investigate money laundering crimes carried out by members of the Indonesian National Armed Forces. Thesis. Jember: Master of Law Study Program, Faculty of Law, University of Jember.

[17] Waluyo, B. (2008). Criminal and sentencing. Jakarta: Sinar Graphic, p. 45.

[18] Dharana Lastarya, Drugs, Need to Know It. Experts, Jakarta 2006, Pg. 15

[19] Julianan Lisa FR, Nengah Sutrisna W, Narcotics, Psychotropics and mental disorders, Nuha Medika, Yoygakarta, 2013, p.2.

[20] Hari Sasangka, Narcotics and Psychotropics in Criminal Law, Bandung: Mandar Maju, 2003, p. 24-25

[21] Kholik syaifullah, et al. 2014. Factors Affecting Drug Abuse in Drug Rehabilitation Clients at the Drug Polyclinic Rsj Sambang Lihu. Vol 5 No 1.

[22] Wijayanti, Daru. 2016. Mental revolution: Stop Drug Abuse. Indoliteration. Bantul, Yogyakarta, p. 27.

[23] Asni M, Rahma, Mukhsen Sarak. 2013. Factors Associated With Narcotics Abuse And Drug Addictive Substances) In Adolescents At Kartika Wirabuana XX-1 Senior High School Makassar. Faculty of Health, Hasanuddin University Makassar.

[24] Kunarto, Police Organizational Behavior, Cipta Manunggal, Jakarta, 2001, page 100

[25] Atwari Bajari, Street Children Communication Dynamics and Deviant Child Behavior (Bandung: Humanities, 2012)

[26] Wagiati Soetedjo, Melani, Child Criminal Law (Bandung: Refika Aditama, 2013), p. 49
[27] Bismar Siregar, Abdul Hakim Garuda Nusantara, Suwanti Sisworahardjo, Arif Gosita, Law and the Rights of the Child (Jakarta: CV Rajawali, 1986), p. 23

[28] Nasharina, Legal Protection for Children in Indonesia (Jakarta: Rajawali Pers, 2011), p. 3

[29] Junaidi, et al, Cooperation between BNN and Police in Combating Drug Abuse in Rappocini District, Makassar City, MODERAT Journal, Volume 5, Number 1, February 2019, pp. $81-95$

[30] Siswantoro Sunarso, Psychotropic Law Enforcement, in the Sociological Study of Law, Jakarta: PT Grfindo Persada. 2004, p. 141.

[31] Soedjono Dirdjosisworo (II), Socio-Criminology of the Practice of Social Sciences in Crime Studies, Bandung: Sinar Baru. 1984. p. 138

[32] Djoko Prakoso, Polri as Investigator in Law Enforcement, Jakarta: Bina Aksara. 1987, p. 21.

[33] Momo Kelana, Police Law, Jakarta: Gramedia Widia Sarana Indonesia. 1994, p. 65

[34] Satjipto Raharjo, Civilian Police for Social Change in Indonesia, Jakarta. 2002, p. 32.

[35] Warsito Hadi Utomo, Police Law in Indonesia, Jakarta: Pustaka Achievements. 2005, p. 43

[36] Kusno Adi, Criminal Policy in Combating Narcotics Crime by Children, Malang: UMM Press. 2009.

[37] Soedjono Dirdjosisworo, 1990, Indonesian Narcotics Law, PT Citra Aditya Bakti, Bandung, p.35

[38] Moch Sulman, 1999, Let's Unite to Eradicate Drug Abuse (Naza), BP. Dharma Bakti, p.12.

[39] Barda Nawawi Arief, 2007, Problems of Law Enforcement and Criminal Law Policy in Combating Crime, Kecana Prenada Media Group, Jakarta, p.78. 